\title{
$\therefore \bullet: 019$
}

Volume 12 Part 1
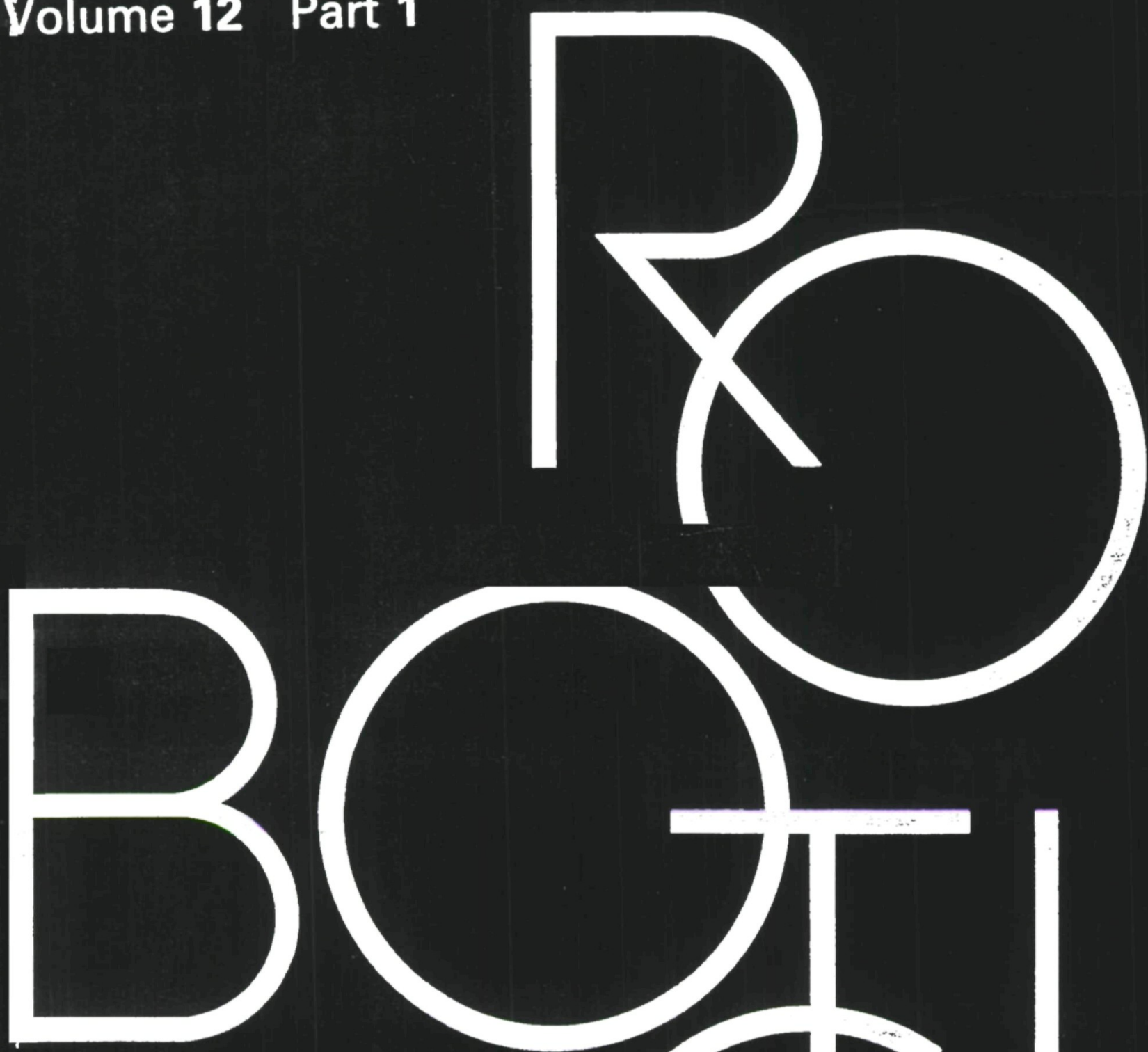

Aciol 


\section{FITTOR:}

Professor J. Rose (Hon. Director of the World Organisation of Systems and Cybernetics;

Visiting Professor, University of Central

Lancashire, UK) 5 Margate Road

St Annes-on-Sea, Lancs. FY8 3EG England

\section{DEPUTY EDITORS:}

Dr E.W. Kent, National Institutes of Standards and

Technology, Robot Systems Division, Bldg. 220,

Rm. B-124, Gaithersburg, MD 20899, USA

Professor R.A. Jarvis,

Dept. of Electrical Engineering, Monash University, Clayton, Victoria 3168, Australia

Profes̀sor S. Arimoto, Dept. of Mathematical Engineering and Information Physics, University of Tokyo, Bunkyo-ku, Tokyo 113, Japan

Professor W. Khalil

Laboratoire d'Automatique de Nantes URA 823, . École Centrale de Nantes, 1 , rue de la Noë, 44072 Nantes cedex 03, France

\section{EDITOR, ROBOTICS REPORTS AND SURVEYS}

Professor B.H. Rudall, School of Mathematics and Computer Science, University College of North Wales, Bangor, Gwynedd LL57 2UW, UK

\section{EDITORIAL BOARD}
I. Aleksander, UK
A.M. Andrew, UK
T. Bock, Germany
S.H. Cho, Korea
K. Desoyer, Austria
J.F. Engelberger, USA
D.J. Evans, UK
M. Esashi, Japan
P. Gaspart, Belgium
T. Hasegawa, Japan
C.H. Kahng, USA
M. Kassler, Australia
A. Kusiak, USA
B.H. McCormick, USA
E. Nicolau, Romania

and links with master computers and CAD/CAM systems, control devices, the study of kinematics and dynamics involved in robot design, design of effectors and ancillary manipulators, problem solving, robot task planning, intelligibility of skilled motion, world model representation, development of relevant educational courses, training methods, analysis of managerial and social policy, economic and cost problems, and items of theoretical and practical interest. As well as original papers, the journal publishes research notes, book reviews, conference reports and letters to the editor.

\section{(C) Cambridge University Press 1994}

Subscriptions: Robotica (ISSN 0263-5747) is published bi-monthly in January, March, May, July, September and November. The subscription price (excluding VAT) (which includes postage) of Volume 12, 1994 is $£ 149$ net (US \$265 in USA, Canada and Mexico) for institutions and $£ 70$ (US $\$ 119$ in USA, Canada and Mexico) for individuals certifying that the Journal is for their personal use. Single parts, cost $£ 27$ net (US $\$ 47$ in USA, Canada and Mexico) plus postage. Six parts form a volume. EC subscribers (outside the UK) who are not registered for VAT should add VAT at their country's rate. VAT registered subscribers should provide their VAT registration number. Orders, which must be accompanied by payment, may be sent to a bookseller, subscription agent or direct to the publishers: Cambridge University Press, The Edinburgh Building, Shaftesbury Road, Cambridge CB2 2RU (UK). Orders from the USA, Canada and Mexico should be sent to Cambridge University Press, Journals Department, 40 West 20th Street, New York, NY 10011-4211, USA. Copies of the Journal for subscribers in the USA, Canada and Mexico are sent by air to New York to arrive with minimum delay. Japanese prices for institutions (including ASP delivery) are available from Kinokuniya Company Ltd, P.O. Box 55, Chitose, Tokyo. Second class postage paid at New York, NY and additional mailing offices. POSTMASTER: send address changes in USA, Canada and Mexico to Robotica, Cambridge University Press, 110 Midland Avenue, Port Chester, New York, NY 10573-9864.

Copying: This journal is registered with the Copyright Clearance Center, 27 Congress St., Salem, Mass. 01970. Organizations in the USA who are also registered with CCC may therefore copy material (beyond the limits permitted by sections 107 and 108 of US copyright law) subject to payment to CCC of the per-copy fee of $\$ 05.00$. This consent does not extend to multiple copying for promotional or commercial purposes. Code 0263-5747/94/\$5.00+.00.

ISI Tear Sheet Service, 3501 Market Street, Philadelphia, Pennsylvania 19104, USA, is authorised to supply single copies of separate articles for private use only.

Organizations authorized by the Copyright Licensing Agency may also copy material subject to the usual conditions.

For all other use, permission should be sought from Cambridge or the American Branch of Cambridge University Press. 